DOI: $10.4274 /$ tftr. 57070

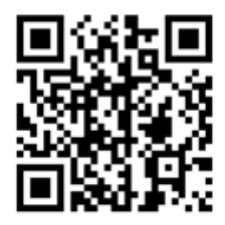

\title{
Çocuk Hastada Ağrısız Diskoid Lateral Menisküs ve Meniskal Yırtık
}

\author{
Painless Discoid Lateral Meniscus Tear of a Pediatric Patient
}

\author{
Mehmet ADAM, PInar DORUK, Berrin LEBLEBICl \\ Başkent Üniversitesi Adana Araştırma ve Uygulama Merkezi, Fiziksel Tıp ve Rehabilitasyon Kliniği, Adana, Türkiye
}

\section{Sayın Editör;}

Çocuklarda kas iskelet şikayetlerinin değerlendirilmesi, yetişkinlere göre farklılıklar göstermekte ve daha fazla önem arz etmektedir. Bu farklılıklardan bazıları, konjenital ve gelişimsel durumların çocuklukta kendini göstermesi, organizmanın hızla büyümesi, daha aktif bir yaşantı sürmesiyle travmalara daha yatkın olabilmesi ve bazı hastalıkların daha sık gözlenebilmesidir.

Diskoid lateral menisküs çocuklarda en sık gözlenen anormal menisküs varyantıdır. Bu durum, menisküsün şeklini ve hareketliliğini etkiler, dizin eklem yapıları arasında normal mekanik ilişkileri değiştirir ve hasarlanmalara yatkınlık yaratır (1).

Travma öyküsü belirtmeyen, diskoid lateral menisküsü ve yırtığı olan, ancak ağrısı olmayan sekiz yaşında erkek hastanın sunulmasıyla, özellikle Fiziksel Tıp ve Rehabilitasyon (FTR) uzmanlığına yeni başlayan genç meslektaşlarımızın bilgilerinin arttıııması amaçlandı.

Ebeveyn eşliğinde FTR polikliniğine başvuran, belirgin bir yakınması olmayan 8 yaşında erkek hastanın ailesi, yaklaşık bir yıldır, travma öyküsü olmaksızın, özellikle koşarken fark edilen sağ dizini açamama ve hafif topallama şikayeti bildiriyorlardı. Dizde hiç şişlik veya kızarıklık oluşmadığı, ağrı, boşalma, kilitlenme hissetmediğini belirtiyordu. Başka eklem yakınması olmayan hastanın sistemik sorgulaması normal sınırlarda olup, daha önce herhangi bir tetkik ve tedavi edilmediğini ifade ediyorlardı.

Özgeçmiş ve soygeçmişi özellik göstermeyen hastanın fizik muayenesinde sistemik muayene normal sınırlardaydı. İnspeksiyonda sağ dizde kızarıklık, şişlik ve kuadriseps atrofisi izlenmiyordu, palpasyonda ağrılı nokta yoktu. Fleksiyonu tam, ekstansiyonu $10^{0}$ kısıtlıydı, ancak eklem hareket açıklığı ağıısızdı. Meniskal testleri negatifti, kas gücü normaldi.

Kalça ve bel bölgesinin muayenesinde, inspeksiyonda skolyoz ve pelvik eğrilik saptanmadı. Palpasyonda paravertebral adale spazmı yoktu. Kalça eklem hareket açıklıkları tamdı. Kontraktür saptanmadı. Bel fleksibilitesi kısıtlanmamıştı. Alt ekstremite uzunluk ölçümlerinde eşitsizlik yoktu.

Laboratuvar incelemelerinde, tam kan sayımı, eritrosit sedimantasyon hızı, C-reaktif protein, rutin biyokimya normal sınırlardaydı. İki yönlü konvansiyonel diz grafisi özellik arz etmiyordu.

Hasta ve ailesine diz koruma eğitimi, aktivite modifikasyonu, dize sıcak paket uygulaması ve germe egzersizleri önerildi. Üç hafta sonrası muayenesinde, ek şikayeti olmayan hastanın bulgularında değişiklik saptanmadı. Manyetik Rezonans Görüntüleme (MRG) planlandı. Sağ diz MRG incelemesinde diskoid lateral menisküs görünümü ve horizontal yırtık saptandı.

Yakınmanın ağrısız olması ve meniskal yırtık bulgularının aşikar olmaması nedeniyle cerrahi tedavi önerilmedi. Sıcak paket uygulaması ve germe egzersizlerine kısa süreli antiinflamatuvar eklendi.

Sekizinci ay kontrolünde menisküs yırtığına ait mekanik semptomlar gözlenmedi. Minimal ekstansiyon kısıtılığı devam ediyordu.

Menisküsler fibrokartilajönöz yapıda olup, aksiyal planda C şekilli, koronal planda kama şekillidir, tibia ve femur arasında temas yüzey alanını arttırırlar. Lateral menisküsün eni ortalama $12 \mathrm{~mm}$, yüksekliği 4 mm'dir. Diskoid menisküs, merkezinin tamamen dolduğu veya çok hafif bir boşluk olmasıyla C şeklinin kaybolduğu bir disk şeklini alma 
halidir. Diskoid menisküsün dış kenarı, normal meniskal kenardan daha kalındır. Bu anatomik değişiklikler normal mekanik ilişkileri değiştirir, hasarlanmaya ve yırtığa yatkınlığı arttıır $(1,2)$.

Menisküslerin embriyolojik yaşamda disk şeklinde başladığına ve sonrasında normal $\mathrm{C}$ şekline ulaştığına inanılıyordu. Diskoid menisküslerin ise merkezi kısımların absorbsiyon yetersizliğine bağlı gelişimsel bir sorun olduğu sanılıyordu (2,3). Ancak sonraki embriyolojik çalışmalarda, normal menisküslerin diskoid prekürsörlerden oluşmadığı, yarım ay görünümün kendi oluşumlarının başlangıcından beri var olduğu gösterilmiştir. Basitçe diskoid oluşumun konjenital anomali veya malformasyon olduğu söylenebilir. Genetik veya ailesel etkenler gelişiminde rol oynadığına inanılmaktadır (1).

Diskoid lateral menisküs ilk defa kadavra üzerinde $1889^{\prime}$ da Young tarafından gösterilmiştir. $1920^{\prime}$ da Kroiss bu durumun kütleyen diz sendromu ile ilişkisini göstermiştir(3). 1974'de Watanabe diskoid menisküsleri tibial platoyu kaplama miktarı ve normal posterior bağlantısına göre komplet (Tip 1), inkomplet (Tip 2) ve Wrisberg ligaman tipi (Tip 3) olarak 3'e ayırmıştır. Günümüzde hala kabul edilen sınıflama budur. En yaygın görülen tipi komplet tiptir. En az görülen tip ise, normal posterior tibial bağlantının bulunmadığı ve normalde olmayan, medial femoral kondilin lateral yüzeyiyle lateral menisküsün arka boynuzuyla ilişkili bir ligamanın olduğu Wrisberg tipidir (4).

Diskoid lateral menisküs, çocuklarda en sık gözlenen menisküs anormalliğidir. Asemptomatik olguların fazla olması, sıklığı hakkında değişken rakamların ortaya çıkmasına neden olur. Artroskopik çalışmalarda \%0,4-16,6 oranlarında görüldüğü ve \%10-20 bilateral gözlenebileceği bildirilmektedir (2). Asya kıtasında daha fazla insidans göstermektedir (1-3). Nadiren diskoid medial ve lateral menisküsler aynı dizde görülebilmektedir (5).

Yırtık yokluğunda Tip 1 ve 2 diskoid lateral menisküsler genelde asemptomatiktir. Yırtık menisküs veya unstabil Wrisberg ligaman tipinde görülen semptomlar değişkendir. En sık görülen yırtık paterni, horizontal yırtıktır (2). Nadir de olsa kova sapı yırtığı olabilmektedir(6). En sık şikayet olan ağrı, Sakman (7) tarafından \%100, Oğuz (8) tarafından \%82 olarak bildirilmiştir. Dizden kütleme sesi gelmesi, boşluk hissi, hareket kısıtııı̆ı, kilitlenme olabilir. Şikayetler herhangi bir travma öyküsü olmaksızın sinsi bir başlangıç gösterebilir. Fizik muayenede lateral eklem mesafesinde hassasiyet ve diz hareketleri sırasında palpabl kütleme tespit edilebilir. Sık olarak bir klik veya kütleme sesi duyulabilir. Efüzyon, kuadriseps atrofisi, ekstansiyonda blok, fleksiyon durumunda yürüme bulunabilir. Provakatif meniskal testlerinde oluşan ağrı, diskoid yapıdan değil, yırtık nedenlidir (1-3). Sunulan olguda, sadece ailesi tarafından gözlenen hareket kısıtıı̆ı̆ı ve fleksiyonda yürüme vardı. Diğer olası şikayetler yoktu. Yırtık nedenli ağrı şikayetinin, oluştuğu anda çocuk ve ailesi tarafından göz ardı edildiği veya hatırlanmadığı düşünülmektedir.

MRG, teşhis için seçilecek görüntüleme yöntemidir. Üç veya daha fazla ardışık 5 mm'lik sagital kesitlerde, menisküsün ön ve arka boynuzları arasında devamlılı̆ın gösterilmesi diskoid menisküs tanısı için gereklidir. Anormal bir kalınlaşmış, papyon görünümü diskoid menisküsü destekler. Bizim olgumuzda her iki MRG bulgusu da izlenmiş̧ir. Ancak Wrisberg ligaman tipinde MRG bazen diskoid menisküsü gösteremeyebilir. Bu durumda artroskopi oldukça yararlıdır. Çok nadiren de olsa osteokondritis dissekans izlenebilir (2). Olgumuzda X-ray grafiler normal sınırlardaydı, MRG ile diskoid lateral menisküs teşhisi rahatlıkla konuldu.

Diskoid lateral menisküslü çocukların çoğu asemptomatik olduğundan nadiren tedavi gerektirir. Hekime başvurmayan, medikal veya cerrahi tedavi önerilmeyen oldukça fazla sayıda hasta olduğu bildirilmektedir. Yırtık olmaksızın, asemptomatik, tesadüfen saptanmış diskoid lateral menisküslere takip dışında bir tedavi önerilmemektedir (3). Ağrı, kilitlenme, şişlik, boşalma hissi gibi mekanik semptomlar olduğunda veya sportif faaliyetlere katılımda kısıtlılık oluyorsa artroskopik cerrahi tedavi önerilir. Optimal cerrahi uygulamanın tam olarak bilinmemesine rağmen, çoğu cerrah tam menisektomiden ziyade kısmi menisektomi, onarım veya diskoid menisküsün normalizasyonunu tercih eder. Tam menisektomiyi tercih eden hekimler, geride bırakılan dokunun kalıtımsal olarak anormal olduğunu ifade ederken, diğerleri, tam menisektomi sonrası dejeneratif eklem hastalığı gelişim riskinin çok büyük olduğunu ve stabil bir periferal doku bırakmak gerektiğini bildirmişlerdir (2,3). Menisektomi için küçük eklemlerin artroskopisine aşina olmayan cerrahlar için, mini artrotomiyi öneren cerrahlar da mevcuttur (9). Hastamızda mekanik semptomlar olmadığından konservatif tedavi planlandı.

Diz ağrısı ve/veya yürüme bozukluğuyla kliniklere başvuran çocuk hastalarda detaylı bir anamnez ve muayene sonrası, menisküs patolojilerinden olan diskoid menisküsün akılda tutulması gereklidir. Çocuklarda mekanik sorunlar ağrısız olabilmekte ve yavaş gelişen deformiteler gözden kaçabilmektedir.

\section{Çıkar Çatışması:}

Yazarlar herhangi bir çıkar çatışması bildirmemişlerdir.

\section{Kaynaklar}

1. Hart ES, Kalra KP, Grottkau BE, Albright M, Shannon EG. Discoid lateral meniscus in children. Orthop Nurs 2008;27:174-9.

2. Yaniv $M$, Blumberg $N$. The diskoid meniscus. J Child Orthop 2007;1:89-96.

3. Kelly BT, Green DW. Discoid lateral meniscus in children. Curr Opin Pediatr 2002;14:54-61.

4. Andrish JT. Meniscal injuries in children and adolescents: Diagnosis and management. J Am Acad Orthop Surg 1996;4:231-7.

5. Kim SJ, Lubis AM. Medial and lateral discoid menisci: a case report. Sports Med Arthrosc Rehabil Ther Technol 2010;2:21.

6. Yalçın N, Bektaşer B, Çiçekli O, Doğan M. Altı yaşındaki kız hastada diskoid lateral menisküsün kova sapı yırtığı. Acta Orthop Traumatol Turc 2009;43:528-31.

7. Sakman B, Cilız D, Özal M, Yüksel E. Diskoid lateral menisküsün tanısında MRG'in yeri. Tanısal ve Girişimsel Radyoloji 2001;7:71-4.

8. Oğuz T, Solak Ş, Çolakoğlu T, Bektaşer B. Lateral menisküs yırtıklarında artroskopik tedavi. Artroplasti Artroskopik Cerrahi 2004;15:90-3.

9. Krause FG, Haupt U, Ziebarth K, Slongo T. Mini-arthrotomy for lateral discoid menisci in children. J Pediatr Orthop 2009;29:130-6. 